\title{
Enhancement of chemopreventive properties of young green barley and chlorella extracts used together against colon cancer cells
}

\author{
Marta Kinga Lemieszek ${ }^{1, A-F \oplus}$, Wojciech Rzeski ${ }^{1, A, F \oplus}$ \\ ${ }^{1}$ Department of Medical Biology, Institute of Rural Health, Lublin, Poland \\ A - Research concept and design, B - Collection and/or assembly of data, C - Data analysis and interpretation, \\ $D$ - Writing the article, E-Critical revision of the article, F- Final approval of article
}

Lemieszek MK, Rzeski W. Enhancement of chemopreventive properties of young green barley and chlorella extracts used together against colon cancer cells. Ann Agric Environ Med. 2020; 27(4): 591-598. doi: 10.26444/aaem/130555

\begin{abstract}
Introduction and objective. Young green barley and chlorella are listed as a panacea for a whole range of disorders, including diabetes, cardiovascular disease, infections, and hypercholesterolaemia. The first reports have appeared presenting the anticancer properties of these products. The present study is an attempt to extend this knowledge with particular emphasis on the possibility of using young green barley, chlorella, and their combination in colon cancer chemoprevention.

Materials and method. Extracts of young green barley $(\mathrm{YB})$ and chlorella $(\mathrm{CH})$, as well as their combination $\mathrm{MIX}(\mathrm{YB}+\mathrm{CH}$; 1:1), were examined. The influence of the extracts on viability and proliferation of human colon epithelial CCD841 CoN cells was analyzed by LDH and MTT assays. Anticancer properties of extracts were screened on human colon adenocarcinoma cell line HT-29 by MTT and BrdU assays. Changes in cells morphology in response to extracts were investigated after MayGrünwald-Giemsa staining.

Results. Extracts used together or separately did not affect the viability and proliferation of CCD841 CoN cells. Simultaneously, YB, CH and MIX inhibited proliferation of HT-29 cells in a dose-dependent manner. Furthermore changes in the morphology of HT-29 cells treated with YB, CH and MIX suggested necrosis induction. Performed studies also revealed that MIX induced a stronger antiproliferative effect than their individual ingredients; however, the discovered enhancement of anticancer properties was weaker than the sum of the effects of YB and CH creating MIX.

Conclusions. The study demonstrates great chemopreventive properties of young green barley and chlorella water extracts and their combination in in vitro model of colon cancer. The anticancer properties of the investigated extracts were significantly enhanced after combining, without an increase of their toxicity against normal cells.
\end{abstract}

\section{Key words}

Hordeum vulgare, Chlorella pyrenoidosa, super-food, functional food, chemoprevention, colon cancer

\section{INTRODUCTION}

Colorectal cancer is a growing health and economic problem in the modern world. Global Cancer Statistics 2018 produced by the International Agency for Research on Cancer revealed that colorectal cancer is the third most common cancer and the second cause of cancer death worldwide [1]. According to the National Cancer Registry, in 1980-2010 there was a 4 -fold increase in the incidence in men and a 3 -fold increase in women, with an increase in mortality by $50 \%$ in men and $30 \%$ in women. Unfortunately, the forecasts for the coming years indicate an upward trend [2]. These data tend to intensify efforts to develop new, more effective strategies for the prevention and treatment of this dangerous disease. Many studies have shown that a reduction in the incidence and mortality rates due to colorectal cancers is possible thanks to screening tests aimed at detecting cancer at an early stage of development, giving a chance for a full recovery. Unfortunately, at the current stage of medicine development, the above-mentioned prevention strategy has limited use in the fight against this group of cancers, but in the future it may play a key role [3].

Address for correspondence: Marta Kinga Lemieszek, Department of Medical Biology, Institute of Rural Health, Lublin, Poland

E-mail: martalemieszek@gmail.com

Received: 03.07.2020; accepted: 17.11.2020; first published: 30.11 .2020
A much better chance of preventing the colon cancer plague is by chemoprevention - understood as a method of preventing cancer by taking substances that can stop or slow down carcinogenesis, or affect the regression of already existing changes [4]. Due to the basic requirement of chemoprevention regarding the use of non-toxic substances at the early stages of the disease's development, or long before the first symptoms appear, it seems justified to look for chemotherapeutics among the components of the daily diet. This concept is a reflection of the idea formulated by Hippocrates 'Let food be your medicine and medicine be your food'. Furthermore, it is also in line with current trends in health sciences which, based on the results of clinical and population studies, indicate that rational, proper nutrition is one of the main factors in the prevention of non-communicable diseases, including colon cancers $[5,6]$.

Chlorella vulgaris and Chlorella pyrenoidosa are green unicellular microalgae with a long history of use, especially in Asia, as a food source and contains a unique and diverse composition of functional ingredients including polysaccharides, proteins, fatty acids, vitamins and minerals [7]. The seedlings of barley plant Hordeum vulgare L. up to 200 hours after germination are referred to as young green barley. Its beneficial impact on the human body is associated mostly with a wide spectrum of enzymes, vitamins, minerals, fatty acids, as well as essential amino acids [8]. Products based 
on young green barley and chlorella are listed as a panacea for a whole range of disorders, including diabetes, cardiovascular disease, bacterial and viral infections, hypercholesterolaemia, overweight and obesity. The advantageous impact on digestion and general detoxification of the body have also been reported [7, 8]. Furthermore, several studies - especially in vitro tests - revealed anticancer properties of these green foods. Extracts or the juice of young green barley, as well as pure compounds isolated from them, successfully inhibited the growth and proliferation of the following human cancer cells: leukemia (Jurkat), lymphoma (NALM6, BJAB), breast cancer (MCF7), colon cancer (LS180, HT-29), lung cancer (A549) $[9,10,11,12,13]$. Next to in vitro studies, the anticancer effect of young green barley products was also observed in animals studies e.g. young barley prevented $\mathrm{N}$-methyl-N-nitrosourea-induced mammary carcinogenesis in female rats [Kubatka et al., 2016], while barley sprouts (GBF - germinated barley foodstuff) inhibited the development of azoxymethane-induced colorectal cancer in rats [14]. Chlorella extracts, as well as pore compounds isolated from them, have shown antiproliferative effect against several types of human cancers cells, including cervical cancer (HeLa), colon cancer (HCT116, HCT-8), breast cancer (MCF7), and glioma (A172) [15, 16, 17, 18].

Because of the fact that most people enjoying the benefits of green food simultaneously take two or more superfood products/nutraceuticals, it was decided to check the chemopreventive properties of the combined use of chlorella and young green barley. The presented study therefore investigated and compared the chemoprevention potential of young green barley and chlorella extracts used alone and in combination as MIX. Antiproliferative activity of tested extracts and their combination was tested in human colon adenocarcinoma cell line HT-29, while their cytotoxicity was examined in human colon epithelial cell line CCD841 $\mathrm{CoN}$. The obtained results are the first report on the impact of combined use of young green barley and chlorella on the growth and proliferation of colon cancer cells.

\section{MATERIALS AND METHOD}

Reagents. Unless otherwise indicated, the chemicals used in the study were purchased from Sigma-Aldrich Co. LLC.

Preparation of young green barley and chlorella extracts. Both powders of young green barley juice (Hordeum vulgare) and dried Chlorella (Chlorella pyrenoidosa) were purchase from Green Ways (Prague, Czech Republic). The products in the amount of $5 \mathrm{~g}$ were dissolved in $150 \mathrm{ml}$ sterile water. Extraction was carried out for 24 hours on a rotator at room temperature. The resulting mixture was centrifuged $(4,075$ $\mathrm{x} \mathrm{G}, 10 \mathrm{~min}, 20^{\circ} \mathrm{C}$ ) and the collected supernatant filtered through a microbiological filter. The resulting filtrates were then subjected to a freeze-drying process. The lyophilizates obtained were stored at $-20^{\circ} \mathrm{C}$. Stock solutions of green food products $(25 \mathrm{mg} / \mathrm{ml})$ were prepared by dissolving the young green barley and chlorella lyophilizates in PBS (phosphate-buffered saline). Obtained extract were stored at $-20^{\circ} \mathrm{C}$. Working solutions of both extracts were prepared by dissolving an appropriate stock solution in a culture medium. In the manuscript, the young green barley and chlorella extracts were marked as $\mathrm{YB}$ and $\mathrm{CH}$, respectively.
Cell lines. The human colon adenocarcinoma cell line HT29 was obtained from ECACC (European Collection of Cell Cultures, Centre for Applied Microbiology and Research, Salisbury, UK). The human colon epithelial cell line CCD 841 CoN was purchased from the ATCC (American Type Culture Collection, Menassas, VA, USA). Studies were conducted on cell lines derived from female donors in order to circumvent gender-associated influences [19].

The HT-29 cells were grown in a mixture of Dulbecco's Modified Eagle's Medium (DMEM) and nutrient mixture F-12 Ham (1:1). The CCD $841 \mathrm{CoN}$ cells were cultured in Eagle's Minimum Essential Medium (EMEM). All media were supplemented with 10\% FBS (foetal bovine serum), 100 units/ml penicillin and $100 \mu \mathrm{g} / \mathrm{ml}$ streptomycin. Cells were maintained in a humidified atmosphere of $95 \%$ air and $5 \%$ $\mathrm{CO} 2$ at $37^{\circ} \mathrm{C}$.

LDH assay - extract cytotoxicity assessment. CCD 841 CoN cells were plated on 96-well microplates at a density of $1 \times 10^{5} \mathrm{cells} / \mathrm{ml}(100 \mu \mathrm{l} / \mathrm{well})$. On the following day, the growth medium was removed and the cells were exposed to a series of tested extracts dilutions. As a positive control of the experiment, $10 \mu \mathrm{M} 5$-fluorouracil (5-FU) and $10 \mu \mathrm{M}$ cis-platin (cis-Pt) were used. Both extracts and cytostatic solutions were prepared in a medium containing 2\% FBS. After 24 hours of exposure, the culture supernatants were collected and transferred to new 96-well plates which were used to execute the LDH assay according to the manufacturer's instructions (In vitro Toxicology Assay Kit, Lactate Dehydrogenase Based). Absorbance was recorded on a microplate reader (BioTek ELx800, Highland Park, Winooski, Vermont, USA) at $450 \mathrm{~nm}$ wavelength. The examination findings were presented as a percentage of $\mathrm{LDH}$ release from cells treated with barley extracts versus cells grown in the control medium (indicated as 100\%).

MTT assay - cell viability/proliferation assessment. HT29 cells and CCD $841 \mathrm{CoN}$ cells were plated on 96-well microplates $(100 \mu \mathrm{l} /$ well $)$ at a density of $3 \times 10^{4}$ cells $/ \mathrm{ml}$ and $5 \times 10^{4}$ cells $/ \mathrm{ml}$, respectively. On the following day, the growth medium was replaced by fresh medium and the cells were exposed to series of dilutions of tested extracts used simultaneously (in a 1:1 ratio) or separately. As a positive control of the experiment, $10 \mu \mathrm{M} 5$-fluorouracil (5-FU) and 10 $\mu \mathrm{M}$ cis-platin (cis-Pt) were used. Both extracts and cytostatic solutions were prepared in a medium containing 10\% FBS. After 96 hours of incubation, the cells were incubated with MTT solution ( $5 \mathrm{mg} / \mathrm{ml}$ ) for $3 \mathrm{~h}$. Formazan crystals were solubilized overnight in SDS buffer pH 7.4 (10\% SDS in $0.01 \mathrm{~N}$ $\mathrm{HCl})$. After this time, the coloured product was quantified spectrophotometrically by measuring the absorbance at $570 \mathrm{~nm}$ wavelength using the microplate reader (BioTek ELx800). Cell proliferation (\%) was expressed as a percentage relative to the untreated control cells.

BrdU assay - cell proliferation assessment. HT-29 cells were plated on 96-well microplates at a density of $5 \times 10^{4}$ cells $/ \mathrm{ml}$ $(100 \mu \mathrm{l} /$ well). The next day, the growth medium was replaced by a fresh medium and the cells were exposed to series of dilutions of tested extracts used simultaneously (in a 1:1 ratio) or separately. As a positive control of the experiment, $10 \mu \mathrm{M} 5$-fluorouracil (5-FU) and $10 \mu \mathrm{M}$ cis-platin (cis-Pt) were used. Both extracts and cytostatic solutions were 
prepared in a medium containing $10 \%$ FBS. Cell proliferation was quantified after 48 hours of treatment according to the manufacturer's instruction, Cell Proliferation ELISA BrdU (Roche Diagnostics GmbH, Penzberg, Germany). The absorbance was measured at $450 \mathrm{~nm}$ wavelength using microplate reader (BioTek ELx800). The influence of the barley extracts on DNA synthesis was presented as a percentage of BrdU incorporation versus control cells (indicated as 100\%).

Morphological examination. To assess changes in cell morphology, May-Grünwald-Giemsa staining was used. HT-29 cells and CCD 841 CoN cells were plated on LabTek Chambers Slide $(450 \mu \mathrm{l} /$ well $)$ at a density of $5 \times 10^{4}$ cells $/ \mathrm{ml}$ and $1 \times 10^{5}$ cells $/ \mathrm{ml}$, respectively. Next day, the culture medium was removed and cells were exposed to the tested extracts at the concentration 500 and $1,000 \mu \mathrm{g} / \mathrm{ml}$, used simultaneously (in a 1:1 ratio) or separately. As a positive control of the experiment, $10 \mu \mathrm{M}$ 5-fluorouracil (5-FU) and $10 \mu \mathrm{M}$ cis-platin (cis-Pt) were used. Both extracts and cytostatic solutions were prepared in a medium containing $10 \%$ FBS. After 48 hours, the cells were stained by the MayGrünwald-Giemsa method. The stained cells were observed by light microscope, Olympus BX51 System Microscope (Olympu Optical Co., Japan).

Statistical analysis. The obtained data were developed in the following programmes: Microsoft Excel 2010 and GraphPrism 5.0. The results were presented as the mean value and standard error of the mean (SEM). The data were analyzed by one-way ANOVA test with Dunnett's or Tukey's post-hoc tests, and column statistics were used for comparisons. Significance was accepted at $\mathrm{p}<0.05$. The $\mathrm{IC}_{50}$ value (concentration causing proliferation inhibition by $50 \%$, compared to control) was calculated using according to the method of Litchfield and Wilcoxon [20].

\section{RESULTS AND DISCUSSION}

Young green barley and chlorella extracts impact on human colon epithelial cells. One of the basic requirements for a chemopreventive agent is the lack of toxicity to normal cells, or at least a clearly lower toxicity to normal cells than to cancer cells. Because of these requirements, the first step in the current study studies was an examination of the cytotoxicity of young green barley and chlorella extracts The extracts' influence on membrane integrity of human colon epithelium CCD841 CoN cells was assessed after 24 hours of cells treatment with the investigated compounds using LDH assay (Fig. 1, top panel). The extracts' impact on proliferation of colon epithelial cells was examined after 96 hours of treatment using MTT test (Fig. 1, bottom panel).

The LDH assay revealed that the tested extracts in the whole range of tested concentrations $(10-1000 \mu \mathrm{g} / \mathrm{ml})$ were not cytotoxic against CCD841 CoN cells. Similar $10 \mu \mathrm{M}$ 5-fluorouracil and $10 \mu \mathrm{M}$ cis-platin used as a positive control

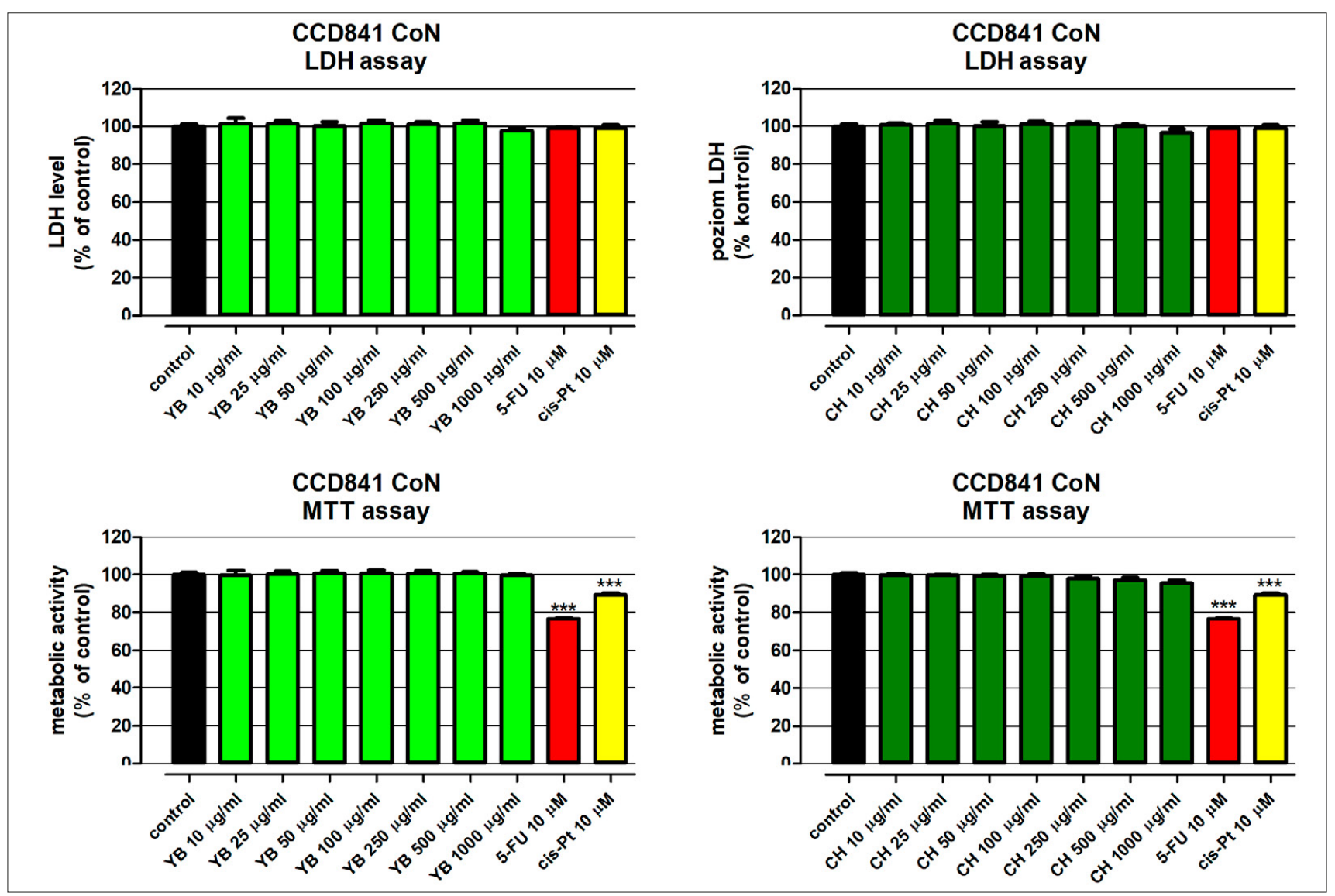

Figure 1. Influence of young green barley and chlorella extracts on membrane integrity of human colon epithelium cell line CCD 841 CoN. Cells were exposed to culture medium alone (control) or young green barley (YB) and chlorella (CH) extracts at concentrations ranging from $10-1000 \mu \mathrm{g} / \mathrm{ml}$ for $24 \mathrm{hours}$ (LDH assay) and for 96 hours (MTT assay). As a positive control of the experiment were used $10 \mu \mathrm{M} 5$-fluorouracil (5-FU) and $10 \mu \mathrm{M}$ cis-platin (cis-Pt). Compounds cytotoxicity was measured photometrically by means of the LDH assay, while compounds impact on cell proliferation was examined photometrically by means of the MTT assay. Results are presented as mean \pm SEM of at least 4 measurements. ${ }^{* * *} \mathrm{p}<0.001$ vs. control, one-way ANOVA test; post hoc test: Dunnett 
of the experiment also did not affect the LDH release from epithelial cells. The MTT assay showed that both investigated extracts in the whole range of tested concentrations did not affect human colon epithelial cells proliferation. On the contrary, as expected, $10 \mu \mathrm{M} 5$-fluorouracil and $10 \mu \mathrm{M}$ cis-platin decreased metabolic activity of CCD841 CoTr cells by $23.2 \%$ and $10.6 \%$, respectively. Data obtained from YB correspond with earlier studies by the authors which demonstrated that juice and young green barley water extract had low cytotoxicity on human colon epithelial cell lines CCD841 CoTr and CCD841 CoN $[9,10]$, nor did they impact on the proliferation of CCD841 CoN cells [9].

It should be noted that the water extract of young green barley used in the current study was prepared in a different way to that of the previously tested extract. Furthermore, only one of four previously tested extract was prepared on the basis of the powder of young green barley juice, which was used in the presented study. In the case of chlorella extract, the results of studies by Hust et al. showed no toxic effect of Chlorella vulgaris and Chlorella sorokiniana extracts in porcine intestinal epithelial cell line IPEC-J2, but revealed their protective properties under stressed conditions induced by enterotoxigenic Escherichia coli [21].

Young green barley and chlorella extracts impact on the proliferation of human colon cancer cells. In the next step, the influence of young green barley and chlorella extracts on the proliferation of human colon adenocarcinoma HT-29 cells were examined by MTT and BrdU tests. The study was conducted after 96 hours (MTT test) and 48 hours (BrdU test) of cells treatment with the tested compounds (Fig. 2).

MTT assay revealed that young green barley extract at the concentration of $10 \mu \mathrm{g} / \mathrm{ml}$ significantly increased the metabolic activity of colon cancer cells. Nevertheless, YB in concentrations of $25-1,000 \mu \mathrm{g} / \mathrm{ml}$ decreased in a dose-dependent manner the proliferation of HT-29 cells $(\mathrm{IC} 50=537 \mu \mathrm{g} / \mathrm{ml})$. Chlorella extract in the whole range of tested concentrations, decreased the metabolic activity of HT-29 cells; the observed effect was dose-dependent (IC50 $=25 \mu \mathrm{g} / \mathrm{ml}$ ). It should be noted that the antiproliferative effect of all the tested concentrations of $\mathrm{CH}$ was stronger than the effects induced by $10 \mu \mathrm{M} 5$-fluorouracil or $10 \mu \mathrm{M}$ cis-platin. Comparison of the effect of YB and cytostatics showed that the tested extract in concentrations from 100 - 1,000 $\mu \mathrm{g} / \mathrm{ml}$ worked more strongly than $10 \mu \mathrm{M}$ cis-platin; however, only the highest dose of $\mathrm{YB}$ revealed stronger than $10 \mu \mathrm{M} 5$-fluorouracil antiproliferative properties.

The observed decrease in metabolic activity after HT-29 cells treatment with young green barley extract, corresponds with earlier results obtained by the authors; nevertheless, YB chemopreventive properties measured by IC50 value reveled that the tested extract has stronger antiproliferative effect than HWE (young barley water extract; IC50 = $700 \mu \mathrm{g} / \mathrm{ml}$ ) and HJE (young barley juice extract; IC50 = 2,400 $\mu \mathrm{g} / \mathrm{ml}$ ), described by Czerwonka et al. [10]. On the other hand, YB revealed weaker anticancer properties against HT-29 cells

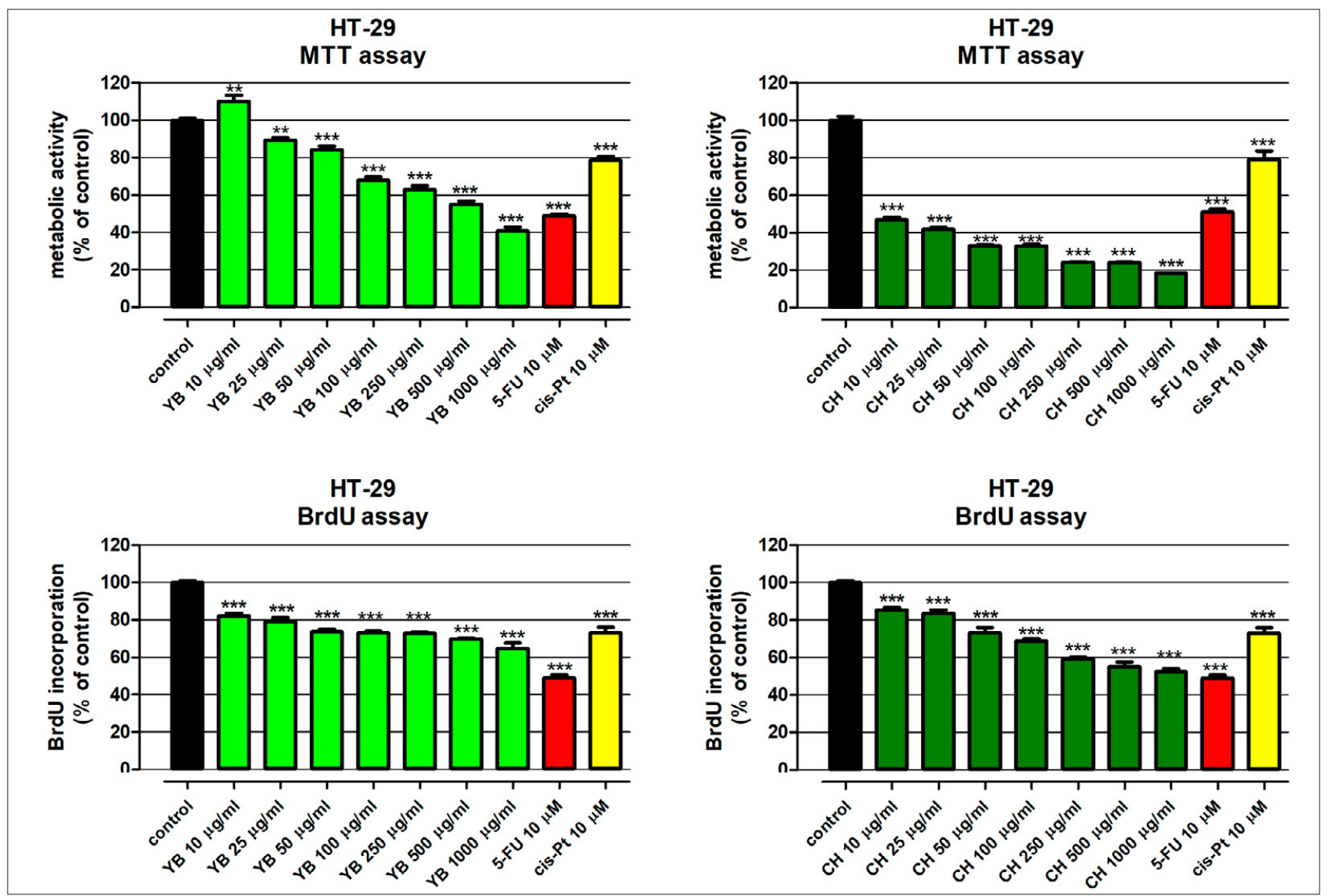

Figure 2. Antiproliferative effect of young green barley and chlorella extracts in human colon adenocarcinoma cell line HT-29. Cells were exposed to culture medium alone (control) or young green barley (YB) and chlorella (CH) extracts at concentrations ranging from 10-1000 $\mu \mathrm{g} / \mathrm{ml}$ for 96 hours (MTT test) or $48 \mathrm{hours}$ (BrdU test). As a positive control of the experiment were used $10 \mu \mathrm{M} 5$-fluorouracil (5-FU) and $10 \mu \mathrm{M}$ cis-platin (cis-Pt). Cell proliferation was measured photometrically by means of the MTT assay or the BrdU assay. Results are presented as mean \pm SEM of 6 measurements. ${ }^{* *} p<0.01$ vs. control, ${ }^{* * *} p<0.001$ vs. control, one-way ANOVA test; post hoc test: Dunnett 


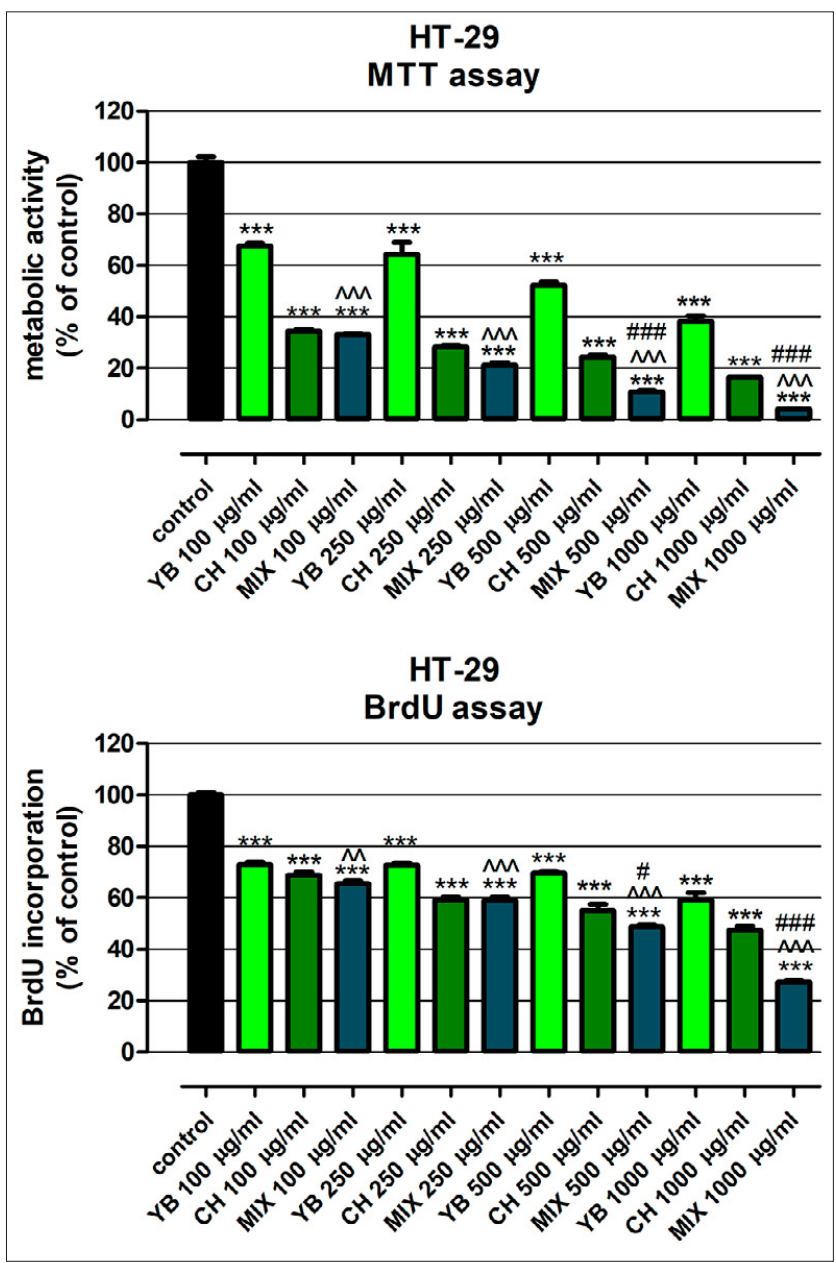

Figure 3. Enhancement of the antiproliferative effect of young green barley and chlorella extracts against human colon adenocarcinoma cell line HT-29. Cells were exposed to culture medium alone (control) or young green barley $(\mathrm{YB})$ and chlorella $(\mathrm{CH})$ extracts at concentrations $100,250,500$ and $1000 \mu \mathrm{g} / \mathrm{ml}$ used separately or used together in a 1:1 ratio as a MIX for 96 hours (MTT test) or 48 hours (BrdU test). Cell proliferation was measured photometrically by means of the MTT assay or the BrdU assay. Results are presented as mean \pm SEM of 6 measurements. ${ }^{* * *} p<0.001$ vs. control; $\wedge \wedge p<0.01 \mathrm{MIX} v$ s. $Y B$ (comparison within corresponding concentrations of $Y B$ ) $; \wedge \wedge \wedge p<0.001 \mathrm{MIX}$ vs. YB (comparison within corresponding concentrations of $Y B$ ); $\# p<0.05$ MIX vs. CH (comparison within corresponding concentrations of $\mathrm{CH}$ ); \#\#\# $\mathrm{p}<0.001 \mathrm{MIX}$ vs. $\mathrm{CH}$ (comparison within corresponding concentrations of $\mathrm{CH}$ ); One-way ANOVA test; post hoc test: Tuckey

than YGB GW (water extract of young green barley dried juice; IC50 $=294 \mu \mathrm{g} / \mathrm{ml}$ ) and YGB INT (water extract of ground dried barley grass; IC50 $=144 \mu \mathrm{g} / \mathrm{ml}$ ), described by Kawka et al [9]. A significant decrease in metabolic activity in response to young green barley extracts has also been demonstrated in human colon adenocarcinoma cell line LS180 [9]. Furthermore, studies conducted by Madhujith and Shahidi have shown that aqueous methanolic extracts of whole kernels from six different barley cultivars significantly inhibited the proliferation of human colorectal adenocarcinoma cell line Caco-2. The mentioned extracts inhibited cancer cells proliferation in the range of $29.3 \%-51.2 \%$ at $0.5 \mathrm{mg} / \mathrm{ml}$ and $9.3 \%-15.9 \%$ at $0.05 \mathrm{mg} / \mathrm{ml}$ after 96 hours of incubation [22]. The observed beneficial effect of $\mathrm{CH}$ against HT-29 cells supports results obtained by Cha et al. They showed, that semipurified extracts of C. ellipsoidea and C. vulgaris inhibited the proliferation of human colorectal carcinoma cell line HCT116 in a dose-dependent manner, obtaining IC50 values of $40.73 \mu \mathrm{g} / \mathrm{ml}$ and $40.31 \mu \mathrm{g} / \mathrm{ml}$, respectively [23]. Similarly, the MTT test conducted by Karakas et al. revealed that $C$. protothecoides extract at the concentration of $100 \mu \mathrm{g} / \mathrm{ml}$, decreased HCT 116 cells by $50 \%$, compared to untreated cells [15]. Furthermore, studies by Zhang et al. demonstrated that exopolysaccharides from C. pyrenoidosa at concentration $0.6 \mathrm{mg} / \mathrm{ml}$ inhibited the metabolic activity of human ileocecal colorectal adenocarcinoma cell line HCT-8 by $35.9 \%$, and human colorectal carcinoma cell line HCT116 by $17.2 \%[16]$.

The discovered antiproliferative properties of $\mathrm{YB}$ and $\mathrm{CH}$ were further verified using a more sensitive and specific assay - the BrdU test. This revealed that both $\mathrm{YB}$ and $\mathrm{CH}$ in the whole range of tested concentrations inhibited DNA synthesis in HT-29 cells, and the observed effect was dose-dependent. IC50 values were, $365 \mu \mathrm{g} / \mathrm{ml}$ in the case of YB extract and $767 \mu \mathrm{g} / \mathrm{ml}$ in the case of $\mathrm{CH}$ extract. It is worth noting that $\mathrm{CH}$ at concentration $50 \mu \mathrm{g} / \mathrm{ml}$ and $\mathrm{YB}$ at concentration $100 \mu \mathrm{g} / \mathrm{ml}$ caused inhibition of DNA synthesis at the level of $10 \mu \mathrm{M}$ cis-platin. On the other hand, the antiproliferative effect of $\mathrm{YB}$ and $\mathrm{CH}$ used at concentration $1,000 \mu \mathrm{g} / \mathrm{ml}$ was lower than $10 \mu \mathrm{M}$ of 5 -fluorouracil by $16 \%$ and $4 \%$, respectively. The observed decrease of DNA synthesis in HT29 cells treated with YB extract corresponded with the results of previous studies by the authors of the current study. These studies also showed significant antiproliferative properties of the water extract of young green barley dried juice (YGB $\mathrm{GW}$ ), and the water extract of ground dried barley grass (YGB INT). Nevertheless, comparison IC50 values of YGB GW $(\mathrm{IC} 50=2610 \mu \mathrm{g} / \mathrm{ml})$ and YGB INT $(\mathrm{IC} 50=497 \mu \mathrm{g} / \mathrm{ml})$ revealed that the antiproliferative effect of YB extract was less effective than previously described [9]. Unfortunately, there is no data about the influence of chlorella extract on BrdU incorporation in colon cancer cells, which could be compared with presented results.

The obtained results have demonstrated the significant chemopreventive potential of the tested extracts. Nevertheless, a comparison of the obtained results with the available literature data once again clearly shows how significant influence on the biological activity of extracts has the method of their preparation and the starting material on the basis of which they were obtained.

\section{Antiproliferative effect of the combination of young green} barley and chlorella extracts The pgainst human colon cancer cells. The antiproliferative properties of young green barley and chlorella extracts used separately or used together in a 1:1 ratio as a MIX were examined both by MTT and BrdU tests in human colon adenocarcinoma HT-29 cells. Studies were conducted after 96 hours (MTT test) and 48 hours (BrdU test) of cells treatment with tested compounds (Fig. 3). Both MTT and BrdU assays revealed that the combination of the tested extracts (MIX) induced stronger antiproliferative activities than individual MIX ingredients, especially YB extract. The decrease in colon cancer cell proliferation in response to MIX was significantly higher than the effect observed in HT-29 cells treated with YB at the same concentration as used in the compered MIX. On the contrary, differences between HT-29 cells metabolic activity and DNA synthesis recorded after cells treatment with MIX $100 \mu \mathrm{g} /$ $\mathrm{ml}$ vs. CH $100 \mu \mathrm{g} / \mathrm{ml}$ and MIX $250 \mu \mathrm{g} / \mathrm{ml}$ vs. CH $250 \mu \mathrm{g} /$ $\mathrm{ml}$, were not statistically significant. Evident improvement in the antiproliferative activity of both $\mathrm{YB}$ and $\mathrm{CH}$ extracts was observed only in the case of MIX $500 \mu \mathrm{g} / \mathrm{ml}$ and MIX $1,000 \mu \mathrm{g} / \mathrm{ml}$. Nevertheless, the enhancement of $\mathrm{YB}$ and $\mathrm{CH}$ 


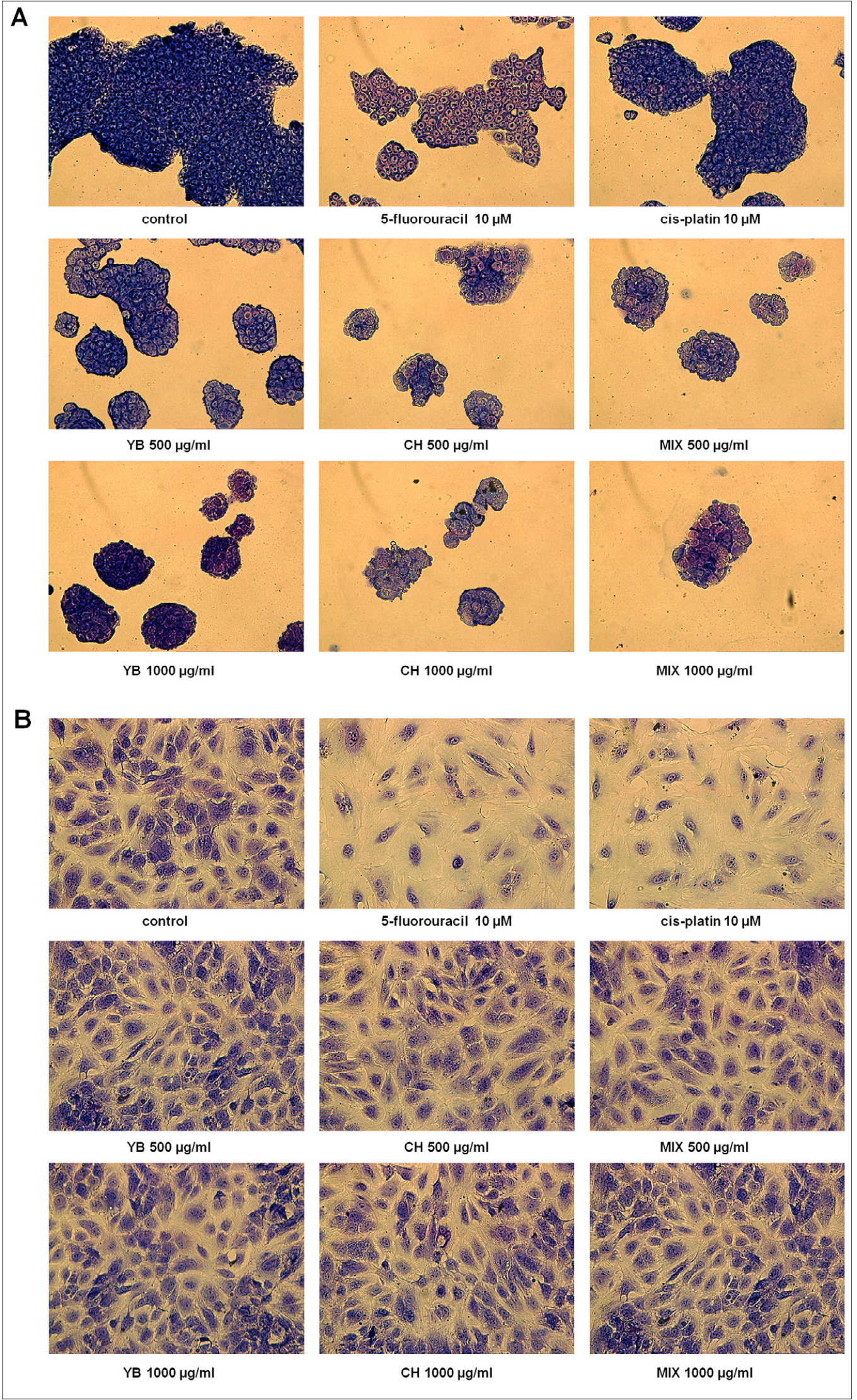

Figure 4. Impact of young green barley and chlorella extracts on the morphology of human colon adenocarcinoma cell line HT-29 (A) and human colon epithelial cell line CCD841 CoN (B). Representative pictures were obtained from two independent experiments (magnification $\times 400)$. Cells were exposed 48 hours to culture medium alone (control) or young green barley (YB) and chlorella (CH) extracts at concentration $500 \mathrm{\mu g} / \mathrm{ml}$ used separately or used together in a 1:1 ratio as a MIX. As a positive control of the experiment were used $10 \mu \mathrm{M}$ 5-fluorouracil (5-FU) and $10 \mu \mathrm{M}$ cis-platin (cis-Pt). Changes in cell morphology were visualized by the May-GrünwaldGiemsa staining method and examined under light microscopy. 
extracts antiproliferative abilities observed in both MIX $500 \mu \mathrm{g} / \mathrm{ml}$ and MIX $1000 \mu \mathrm{g} / \mathrm{ml}$ was weaker than the sum of the effects of the individual ingredients.

The presented data is the first evidence showing enhancement of chemopreventive properties of young green barley and chlorella extracts used in combination against colon cancer cells. The beneficial effects of combined use of young green barley and chlorella extracts may be the effect of the accumulation of phytochemicals with antiproliferative properties presented in tested extracts. This hypothesis is supported observations of other scientists whose results revealed that the anticancer effect of different plant extracts has stronger anticancer activities than single phytochemicals present in these extracts. Because of that, a diet rich in fruits and vegetables containing the complex mixture of phytochemicals has better health benefits, including chemopreventive properties, than pure anticancer substances isolated from plants $[24,25,26]$.

Induction of morphological changes on human colon epithelial cells and human colon cancer cells by young green barley and chlorella extracts. Changes in the morphology of human colon epithelial cell line CCD841 CoN and human colon adenocarcinoma cell line HT-29 were investigated after 48 hours of cells treatment with young green barley and chlorella extracts, used separately or together in a 1:1 ratio as a MIX. After treatment, the cells were stained with May-Grünwald-Giemsa and the induced alterations were visualized by light microscopy (Fig. 4).

As presented in Fig. 4A, all the examined compounds significantly inhibited the proliferation of HT-29 cells, and the strongest antiproliferative effect was observed in colon cancer cells treated with chlorella extract and MIX. Next to the inhibition of cancer cell proliferation, the studied compounds (except cis-platin) also affected HT-29 cells morphology. YB in both tested concentrations (500 and $1,000 \mu \mathrm{g} / \mathrm{ml}$ ) caused HT-29 cell swelling, while colon cancer cells treated with $\mathrm{CH}(500$ and $1,000 \mu \mathrm{g} / \mathrm{ml}$ ) and MIX, were characterized by vacuolization, loss of cell membrane integrity and swelling. These changes suggest the induction of necrosis in HT-29 cells in response to tested extract used alone and in combination. 5-fluorouracil alkalinized the cytoplasm of colon cancer cells, which was reflected in the degree of staining intensity. Obtained data correspond with the results of MTT and BrdU assays described above.

Changes in the morphology and growth pattern of HT-29 cells induced by YB extracts were similar with alterations observed by Kawka et al. during examination of previously mentioned young green barley extracts YGB GW and YGB INT [9]. Furthermore, suggestions of necrosis induction in HT-29 cells treated with YB is supported by results obtained by Czerwonka et al., who proved this type of death in human colon cancer cells exposed to water extract of young green barley (HWE) [10]. Nevertheless, Yao et. revealed proapoptotic properties of fermented young green barley extract in the transplantation tumuor model of human HT29 cells in nude mice [27]. Additionally, Cha et al. reported early apoptosis induction in human colorectal carcinoma cell line HCT116 treated with semipurified extracts of $C$. ellipsoidea and C. vulgaris [23]. Studies conducted by Guo et al. also revealed programmed cells induction in human colorectal adenocarcinoma cell line Caco-2 after exposure to aqueous extract from C. pyrenoidosa [28]. Consequently, an unambiguous definition of the mechanism of colon cancer cell death in response to the tested extract and MIX requires a more detailed analysis.

As presented in Fig. 4B, investigated extract used alone or as MIX in both tested concentrations (500 and 1,000 $\mu \mathrm{g}$ / $\mathrm{ml}$ ) did not affect the morphology or growth pattern of human colon epithelial CCD841 CoN cells. At the same time, $10 \mu \mathrm{M} 5$-fluorouracil and $10 \mu \mathrm{M}$ cis-platin reduced the number of CCD841 CoN cells and significantly impacted their morphology - the cell bodies were swollen. No negative effect of aqueous extracts based on young green barley on the growth and morphology of human colon epithelial cells corresponded with the results of previous studies by the authors [9]. A similar influence of chlorella and young green barley mixture on colon epithelial cells is presented here or the first time. Unfortunately, there is a lack of evidence showing the impact of chlorella extracts on the morphology of human colon epithelial cells.

\section{CONCLUSIONS}

The presented results revealed great chemopreventive properties of young green barley and chlorella water extract, as well as their combination in in vitro model of colon cancer. Used together or separately, the studied extracts specifically inhibited the proliferation of human colon cancer cells without any undesirable effect on human colon epithelial cells. Furthermore, the presented anticancer properties of the extracts were significantly enhanced after combination, without increasing their toxicity against normal cells.

The beneficial effect of combined / simultaneous use of young green barley and chlorella seems to be attributed to the complex mixture of phytochemicals present in the studied product; however, further chemical research is required to determine the bioactive compounds. Nevertheless, it needs to be highlighted that the presented study is the first evidence of the anticancer properties of the combination of one of the most popular new superfoods. Furthermore, because of the increasing consumption of these products, further research on the health benefits of their phytochemicals, as well as whole specimens, is warranted. The presented positive results will provide a rationale for the development a new chemopreventive strategy.

\section{Acknowledgment}

The authors acknowledge the support of the Institute of Rural Health in Lublin, Poland, under Project No. 19060, 2019.

\section{REFERENCES}

1. Bray F, Ferlay J, Soerjomataram I, Siegel RL, Torre LA, Jemal A. Global cancer statistics 2018: GLOBOCAN estimates of incidence and mortality worldwide for 36 cancers in 185 countries. CA Cancer J Clin. 2018; 68(6): 394-424.

2. Stewart BW, Wild CP. World Cancer Report 2014. International Agency for Research on Cancer, 2014.

3. Jemal A, Siegel R, Ward E, Murray T, Xu J, Thun MJ. Cancer statistics 2007. Cancer J Clin. 2007; 57: 43-66.

4. Sporn MB, Suh N. Chemoprevention of cancer. Carcin. 2000; 21: 525-530.

5. Lillycrop KA, Burdge GC. Epigenetic mechanisms linking early nutrition to long term health. Best Pract Res Clin Endocrinol Metab. 2012; 26: 667-676. 
6. Donaldson MS. Nutrition and cancer: a review of the evidence for an anti-cancer diet. Nutr J. 2004; 3: 19.

7. Panahi Y, Darvishi B, Jowzi N, Beiraghdar F, Sahebkar A. Chlorella vulgaris: a multifunctional dietary supplement with diverse medicinal properties. Curr Pharm Des. 2016; 22(2): 164-173.

8. Kawka K, Lemieszek MK. Prozdrowotne właściwości młodego jęczmienia. Med Og Nauk Zdr. 2017; 23(1): 7-12.

9. Kawka K, Lemieszek MK, Rzeski W. Chemopreventive properties of young green barley extracts in in vitro model of colon cancer. Ann Agric Environ Med. 2019; 26(1): 174-181.

10. Czerwonka A, Kawka K, Cykier K, Lemieszek MK, Rzeski W. Evaluation of anticancer activity of water and juice extracts of young Hordeum vulgare in human cancer cell lines HT-29 and A549. Ann Agric Environ Med. 2017; 24(2): 345-349.

11. Kubatka P, Kello M, Kajo K, Kruzliak P, Výbohová D, Šmejkal K, et al. Young barley indicates antitumor effects in experimental breast cancer in vivo and in vitro. Nutr Cancer. 2016; 68(4): 611-621.

12. Robles-Escajeda E, Lerma D, Nyakeriga AM, Ross JA, Kirken RA, Aguilera RJ, et al. Searching in mother nature for anti-cancer activity: antiproliferate and pro-apoptic effect elicited by green barley on leukemia/lymphoma cells. PLOS 2013; 8(9): 1-18.

13. Jeong HJ, Lam Y, Lumen BO. Barley lunasin supresses ras-induced colony formation and inhibits core histone acetylation in mammalian cells. J Agric Food Chem. 2002; 50(21): 5903-5908.

14. Kanauchi O, Mitsuyama K, Andoh A, Iwanaga T. Modulation of intestinal environment by prebiotic germinated barley foodstuff prevents chemo-induced colonic carcinogenesis in rats. Oncol Rep. 2008; 20(4): 793-801.

15. Karakaş CY, Tekarslan Şahin H, İnan B, Özçimen D, Erginer YÖ. In vitro cytotoxic activity of microalgal extracts loaded nano-micro particles produced via electrospraying and microemulsion methods. Biotechnol Prog. 2019; 35(6): e2876.

16. Zhang J, Liu L, Ren Y, Chen F. Characterization of exopolysaccharides produced by microalgae with antitumor activity on human colon cancer cells. Int J Biol Macromol. 2019; 128: 761-767.
17. Kubatka P, Kapinová A, Kružliak P, Kello M, Výbohová D, Kajo K, et al. Antineoplastic effects of Chlorella pyrenoidosa in the breast cancer model. Nutrition. 2015; 31(4): 560-569.

18. Kyadari M, Fatma T, Azad R, Velpandian T. Evaluation of antiangiogenic and antiproliferative potential of the organic extract of green algae Chlorella pyrenoidosa. Indian J Pharmacol. 2013; 45(6): 569-574.

19. Nunes LM, Robles-Escajeda E, Santiago-Vazquez Y, Ortega NM, Lema C, Muro A, et al. The gender of cell lines matters when screening for novel anti-cancer drugs. AAPS J. 2014;16(4):872-874.

20. Litchfield JT, Wilcoxon FA. A simplified method of evaluating doseeffect experiments. J Pharmacol Exp Ther. 1949; 96: 99-113.

21. Hulst M, van der Weide R, Hoekman A, van Krimpen M. Transcriptional response of cultured porcine intestinal epithelial cells to micro algae extracts in the presence and absence of enterotoxigenic Escherichia coli. Genes Nutr. 2019; 14: 8.

22. Madhujith T, Shahidi F. Antioxidative and antiproliferative properties of selected barley (Hordeum vulgarae L.) cultivars and their potential for inhibition of low-density lipoprotein (LDL) cholesterol oxidation. J Agric Food Chem. 2007; 55(13): 5018-5024.

23. Cha KH, Song Yi Koo, Dong-Un Lee. Antiproliferative effects of carotenoids extracted from Chlorella ellipsoidea and Chlorella vulgaris on human colon cancer cells. J Agric Food Chem. 2008;56(22): 1052110526.

24. Temple NJ, Gladwin KK. Fruits, vegetables, and the prevention of cancer: research challenges. Nutrition. 2003; 19: 467-470.

25. Sun J, Chu YF, Wu X, Liu RH. Antioxidant and antiproliferative activities of fruits. J Agric Food Chem. 2002; 50: 7449-7454.

26. Chu YF, Sun J, Wu X, Liu RH. Antioxidant and antiproliferative activities of vegetables. J Agric Food Chem. 2002; 50: 6910-6916.

27. Yao F, Zhang JY, Xiao X, Dong Y, Zhou XH. Antitumor activities and apoptosis-regulated mechanisms of fermented barley extract in the transplantation tumor model of human HT-29 cells in nude mice. Biomed Environ Sci. 2017; 30(1): 10-21.

28. Guo W, Zhu S, Feng G, Wu L, Feng Y, Guo T, et al. Microalgae aqueous extracts exert intestinal protective effects in Caco-2 cells and dextran sodium sulphate-induced mouse colitis. Food Funct. 2020;11(1): 1098-1109. 